\title{
PROCEEDING
}
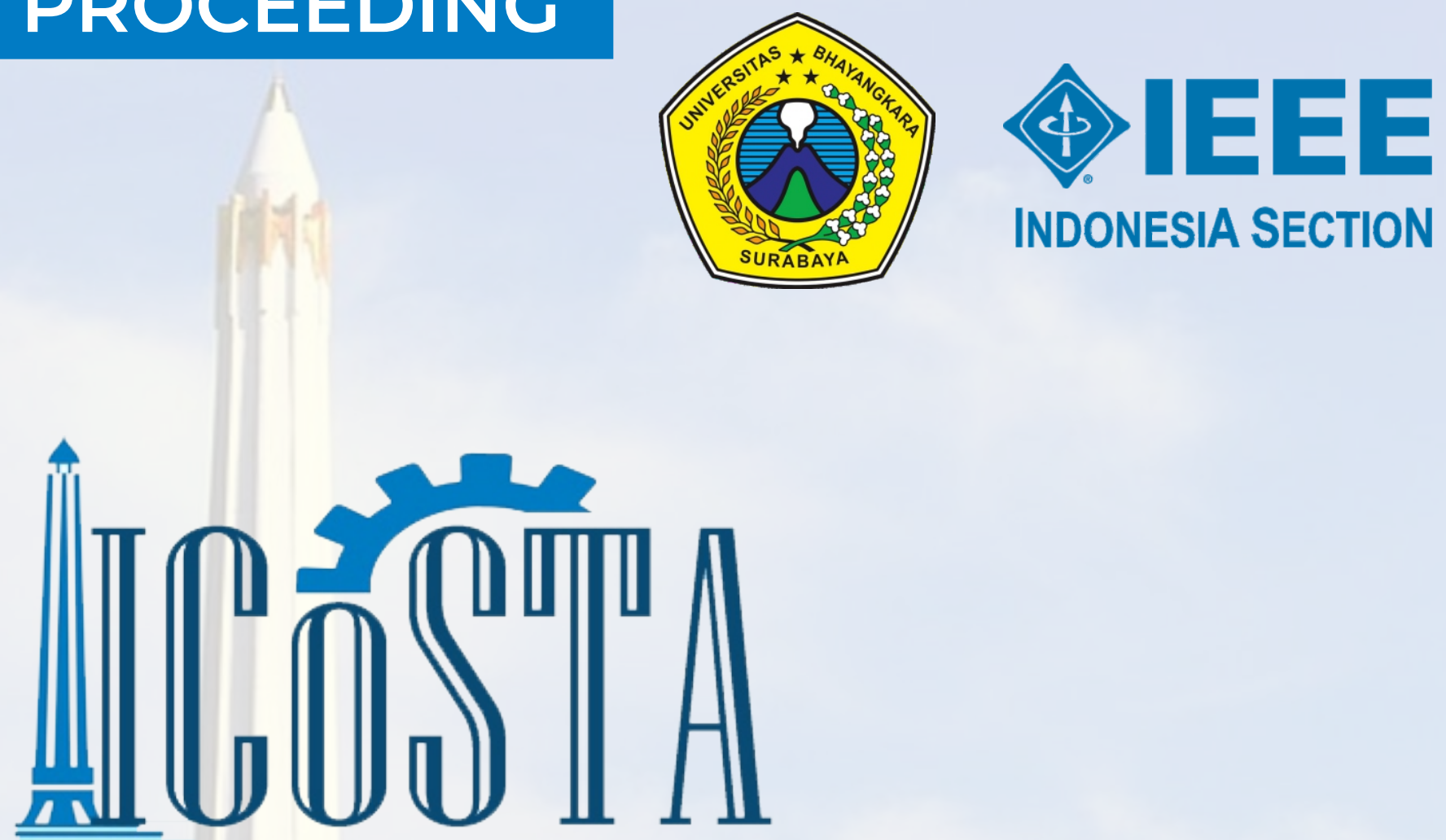

2020 International Conference on Smart

Technology and Applications (ICOSTA)

Empowering Industrial IoT by Implementing Green Technology

for Sustainable Development

IEEE Part Number : CFP200SW-ART

ISBN : 978-1-7281-3083-5

\section{February 2020}

Mercure Hotel Surabaya

JI Raya Darmo 68 - 7860264 SURABAYA 


\section{International Conference on Smart Technology and Applications (ICoSTA)}

\section{Proceeding}

2020 International Conference on Smart Technology and Applications (ICoSTA) took place 20 February 2020 in Surabaya, Indonesia.

$$
\begin{array}{lll}
\text { IEEE catalog number } & : & \text { CFP20OSW-ART } \\
\text { ISBN } & : & 978-1-7281-3083-5
\end{array}
$$

Copyright and Reprint Permission: Abstracting is permitted with credit to the source. Libraries are permitted to photocopy beyond the limit of U.S. copyright law for private use of patrons those articles in this volume that carry a code at the bottom of the first page, provided the percopy fee indicated in the code is paid through Copyright Clearance Center, 222 Rosewood Drive, Danvers, MA 01923. For other copying, reprint or republication permission, write to IEEE Copyrights Manager, IEEE Operations Center, 445 Hoes Lane, Piscataway, NJ 08854.

All rights reserved. Copyright (C) 2020 by IEEE. 


\section{Organizing Committee}

\section{General Chair}

Dr. Rr. Ani Dijah Rahajoe, S.T., M.Cs (Universitas Bhayangkara Surabaya, Indonesia)

\section{General Co-Chair}

Rifki Fahrial Zainal, S.T., M.Kom (Universitas Bhayangkara Surabaya, Indonesia)

\section{Technical Program Committee Chair}

Dr. Ir. Saidah, M.T (Universitas Bhayangkara Surabaya, Indonesia)

\section{Technical Program Committee Co-Chair}

Dr. Bambang Purwahyudi S.T., M.T (Universitas Bhayangkara Surabaya, Indonesia)

\section{Advisory Board}

Prof. Wu Xi Ph.D (Chengdu University of Information Technology, China)

Prof. Lin Peng Ph.D (Shantou University, China)

Prof. Dr. D. K. Lobiyal (Jawaharlal Nehru University, India)

Prof. Dr. Taufik (California Polytechnic State University, USA)

Prof. Sun Xingyang (Yangzhou Polytechnic Institute, China)

Prof. Dr. Ir Jazi Eko Istiyanto,M.Sc., IPU,ASEAN Eng (Universitas Gadjah Mada, Indonesia)

Prof. Dra. Sri Hartati, M.Sc.,P.hD (Universitas Gadjah Mada, Indonesia)

Prof. Dr. Ir. Mochamad Ashari, M.Eng. (Institut Teknologi Sepuluh Nopember, Indonesia)

Prof. Dr. Ir. Mauridhi Hery Purnomo, M.Eng. (Institut Teknologi Sepuluh Nopember, Indonesia)

Prof. Ir. H. Ontoseno Penangsang, M.Sc, Ph.D (Institut Teknologi Sepuluh Nopember, Indonesia)

Prof. Dr. Ir. Adi Supriyanto MT (Institut Teknologi Sepuluh Nopember, Indonesia)

Prof. Dr. Ir. Achmad Jazidie, M.Eng (Institut Teknologi Sepuluh Nopember, Indonesia)

Prof. Dr. Yoyon K. Suprapto (Institut Teknologi Sepuluh Nopember, Indonesia) 
Prof. Dr. Gamantyo Hendrantoro (Institut Teknologi Sepuluh Nopember, Indonesia)

Prof. Dr. Ir. Mohammad Nuh, DEA (Institut Teknologi Sepuluh Nopember, Indonesia)

Prof. Dr. Anton Satri Prabuwono (King Abdul Aziz University, Saudi Arabia)

Prof. Dr. Eng. Safarudin (Universitas Hasanuddin, Indonesia)

Prof. Ir. Rukmini Sari Hartati MT., Ph.D (Universitas Udayana, Indonesia)

Prof. Dr. Bambang Riyanto (Institut Teknologi Bandung, Indonesia)

Prof. Dr. Iwa Garniwa (Universitas Indonesia, Indonesia)

Prof. Arif Junaidi (Institut Teknologi Sepuluh Nopember, Indonesia)

Prof. Ida Ayu Giriantari (Universitas Udayana, Indonesia)

Prof. Joko Lianto Buliali Ph.D. (Institut Teknologi Sepuluh Nopember, Indonesia)

\section{Technical Program Committee}

Dr. Adhi Dharma Wibawa (Institut Teknologi Sepuluh Nopember, Indonesia)

Dr. Ir. Dian Retnosavitri (Universitas Dian Nuswantoro, Indonesia)

Dr. Ir. Mohamad Haddin (Universitas Islam Sultan Agung, Indonesia)

Dr. Yusron (Universitas Hasanuddin, Indonesia)

Dr. Muhammad Rivai (Institut Teknologi Sepuluh Nopember, Indonesia)

Dr. Ing. MHD. Reza M.I. Pulungan, S.Si.,M.Sc (Universitas Gadjah Mada, Indonesia)

Afiahayati,S.Kom.,M.Cs.,Ph.D (Universitas Gadjah Mada, Indonesia)

Dr. Ahmad Ashari,M.Kom (Universitas Gadjah Mada, Indonesia)

Dr. Drs. Azhari, MT (Universitas Gadjah Mada, Indonesia)

Drs. Agus Harjoko,M.SC.,Ph.D (Universitas Gadjah Mada, Indonesia)

Dr. Suprapto,M.Kom (Universitas Gadjah Mada, Indonesia)

Drs. Edi Winarko,M.Sc.,Ph.D (Universitas Gadjah Mada, Indonesia)

Dr. Yohanes Suyanto,M.I.Kom (Universitas Gadjah Mada, Indonesia)

Dr. Agfianto Eko Putra, M.Si (Universitas Gadjah Mada, Indonesia)

Dr. tech Khabib Mustofa, S.Si., M.Kom (Universitas Gadjah Mada, Indonesia)

Anny Kartika Sari,S.Si., M.Sc., Ph.D (Universitas Gadjah Mada, Indonesia)

Wahyono, S.Kom., Ph.D (Universitas Gadjah Mada, Indonesia)

Drs. Retantyo Wardoyo,M.Sc., Ph.D (Universitas Gadjah Mada, Indonesia) 


\section{Table of Contents}

Title $\quad$ i

Copyright

Message From The General Chair iii

Speech From The Rector of University of Bhayangkara Surabaya iv

Organizing Committee $\quad$ v

Parallel Class Schedule vi

Table of Contents $\quad$ xxi

Papers

Parallel Class 1

Improved K-Means Algorithm on Home Industry Data Clustering in the Province 1 of Bangka Belitung

Classification of Student Academic Performance using Fuzzy Soft Set 7

Segmentation of Customer Experience of YouTube Streaming Application Users 13 in South Jakarta using K-means Method

Comparison of Distance Function to Performance of K-Medoids Algorithm for $\quad 18$ Clustering

A Survey on Multimodal Information Retrieval Approach 24

Improvement of Data Accuracy on Backpropagation Neural Network-based 30

Automatic Control System for Wheeled Robot

A Review of Iris Recognition System ROI and Accuracy 35

A Survey on Visualization Techniques to Narrate Interpersonal Interactions 41 between Sportsmen

Comparison of SVM and BPNN Methods in The Classification of Batik Patterns 47

Based on Color Histogram And Invariant Moments

\section{Parallel Class 2}

Performance comparison of wireless protocol IEEE 802.11ax vs IEEE 802.11ac $\quad 51$

Improving Intrusion Detection System by Estimating Parameters of Random 56

Forest in Boruta

Pearson Correlation Attribute Evaluation-based Feature Selection for Intrusion $\quad 62$ Detection System

Port Session Communication Analysis Using Density-Based Clustering For Host 67 Anomaly and Risk Activity Analysis 
The QoS Improvement Using CDN for Live Video Streaming with HLS

Detecting Features of Middle Size Soccer Field using Omnidirectional Camera for Robot Soccer ERSOW

Performance Analysis of Self-Organizing Map Method for Wheeled Robot

Control System

Development of Localization Technique using Trilateration Algorithm for E-

Puck2 Robot

Integration of N-GCPSO Algorithm with Spatial Particle Extension Algorithm for Multi-Robot Search

Design of Restaurant Billing System (E Bill Resto) by Applying Synchronization of Data Billing in Branch Companies to Main Companies Based on Rest API

\section{Paralell Class 3}

Automatic Sign of Commencement of Work from Enterprise Resource Planning

Improve Smart Waste Management to Preserve Tourist Attractions Yogyakarta in 110 IoT Environment

Industry 4.0 strategic alignment framework: Multilevel perspective of digital transition in Indonesia

Design of Soil Humidity Monitoring System Using the Internet of Things

Concept and MQTT Protocol

A Change Management Model for Information Systems Implementation

Android Application for Advanced Security System based on Voice Recognition, Biometric Authentication, and Internet of Things

The Combination of Analytical Hierarchy Process and Simple Multi-Attribute Rating Technique for The Selection of The Best Lecturer

Development of Automatic Plant Irrigation System using Soil Moisture Sensors for Precision Agriculture of Chili

Feature Selection Based on Modified Harmony Search Algorithm

\section{Parallel Class 4}

Design and Implementation of an Emergency Datacasting System Using 2-meter Amateur Radio Band

Design of Wireless Electromyography (EMG) Monitoring System for Muscle Activity Detection on Parkinson Disease

Characterization of Magnetic Induction Coil Sensor for Void Detection in Steel Plate

Multiband Microstrip Antenna Design for Radio Frequency Identification (RFID) 170 Application 
Theta, Alpha and Beta Activity in the Occipital Based on EEG Signals for Mental 175 Fatigue in High School Students

The Effect of Harmonics on Purification Scheduling of Transformer Oil Insulation to Restrain The Degradation Rate

An HF Digital Communication System Based on Software-Defined Radio

Capacity Analysis for Hybrid Beamforming MIMO Channel using Discrete

Cosine Transform and Antenna Selection

Solar Energy Monitoring System Design Using Radio Frequency For Remote Areas

\section{Parallel Class 5}

Analysis of Short Circuit on Four Types Wind Power Plants as Distributed Generation

Power Quality Enhancement on Hybrid Power Plants Using Shunt Passive Power 206 Filter and Detuned Reactor

Load Factor Improvement on Daily Load Curve Using Pump Storage to Saving Production Cost

Analysis of Power Transactions on the Integrated Solar Home System

Analysis and Design Implementation of Modulator $\pi / 4$ - Differential Quadrature Phase Shift Keying Low Power Based on FPGA

Fault Tolerant Control for Speed Sensorless of DC Motor

Power Transfer Analysis Using UPQC-PV System Under Sag and Interruption With Variable Irradiance

Fault-Tolerant Control Strategy Based on Reliability and Cost Analysis in Heat Recovery Steam Generator Plant

Design Of One Phase Inverter 250 Watt Third Harmonic Pulse Width Modulation Method In Mini-Grid Photovoltaic

\section{Parallel Class 6}

Data Quality Measures and Data Cleaning for Pattern Analysis Angkot

Transportation in Bandung City

Design and Implementation of IoT-Based Smart Home Voice Commands for disabled people using Google Assistant

Smart Greetthings: Smart Greenhouse Based on Internet of Things for Environmental Engineering

Decentralized Tourism Destinations Rating System Using 6AsTD Framework and Blockchain 
Analysis the Issue of Increasing National Health Insurance (BPJS Kesehatan)

Rates through Community Perspectives on Social Media: A Case Study of Drone Emprit

Analysis of Malang City Readiness in Realizing Smart Tourism with New

Integrated E-Readiness Model

IoT Based: Improving Control System For High-Quality Beef in Supermarkets

Design of Portable Galvanic Skin Response Sensor for Pain Sensor

\section{Parallel Class 7}

Prediction of Bitcoin Price Change using Neural Networks

Generalized Regression Neural Network For Long-Term Electricity Load

Forecasting

Resource Optimization in Heterogeneous Networks Using Discrete Firefly Algorithm

A Review on Question Analysis, Document Retrieval and Answer Extraction Method in Question Answering System

Design of Control Algorithm for Monitoring System and Bridge Control Based on Internet of Things (IoT)

Optimization of DG Placement and size using PSO based on GUI

Natural Tele-manipulation for Robot Movement based on Motion Pattern of Arm Posture

Fault Classification of Induction Motor Using Discrete Wavelet Transform and

Fuzzy Inference System

Faults Identification of Induction Motor Based on Vibration Using Backpropagation Neural Network 


\section{A Review of Iris Recognition System ROI and Accuracy}

\author{
Robby Alphonsus Halim \\ Magister Informatic \\ Universitas Atma Jaya Yogyakarta \\ Yogyakarta, Indonesia \\ robby7370@gmail.com
}

\author{
Andi Wahju Rahardjo Emanuel \\ Magister Informatic \\ Universitas Atma Jaya Yogyakarta \\ Yogyakarta, Indonesia \\ andi.emanuel@uajy.ac.id
}

\begin{abstract}
Iris contains some information about human body and organ condition. Iridology is a scientific study of the iris structure to get some information that represents the condition of the various organs by examining the tissue strengths and weaknesses in the iris. With the rapid development of image processing, iridology has become more popular and reliable. In recent years, many systems that adopt iridology have been developed to diagnose a disease by analyzing a certain part of the iris or so-called Region of Interest (ROI). Typically, iris recognition systems consist of three main functions namely image pre-processing, feature extraction, and classification. This paper shows all the regions that have been studied and the accuracy of their iris recognition system.
\end{abstract}

Keywords-Iridology, Iris Recognition System, ROI, System accuracy.

\section{INTRODUCTION}

The human iris is a ring-shaped part between cornea and pupil (Figure 1). Even though iris is considered as human inner organ, iris can be observed with ease from the exterior [1]. Iris is a screen where nerve systems are located and contain pieces of information about the human body [2]. The scientific study to analyze this information and specify weaknesses in the human body is called iridology. Iridologists examine the iris fiber, color, brightness, and shadings by looking at the iris and claim that iridology can predict the risk of disease because signs that represent body debility will appear in iris earlier than the organ itself. [3].

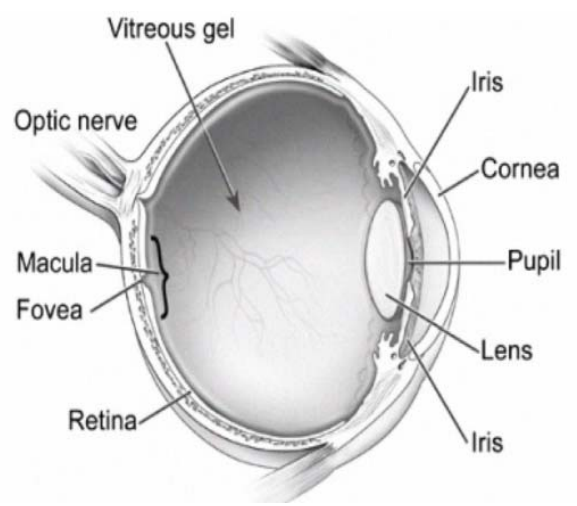

Figure 1. Human iris [1].

In iridology, there is a chart that can be used to find the organ that the iris represents namely the iridology chart (Fig. 2). The iridology chart shows the left side and the right side of an iris image with highlighted regions for each organ. This chart used by iridologists to compare the signs such as a circular iris fiber, circular ring, dark spot, etc, of the patient iris with the healthy iris. Based on the observation, they will specify which part of the body is weak or susceptible to suffer from diseases sooner than actual symptoms[4]. Typically, iridology charts divide an iris image into 80 to 90 regions [3].

The iris recognition system usually only analyze one region of the iris. Every iris recognition system consists of three main functions. The three main functions of this system are image pre-processing, feature extraction and classification. The image pre-processing function is used to obtain the ROI of the iris from the iris image. Generally, preprocessing is consists of five steps: transform into a greyscale image, iris localization, normalization, histogram equalization, and separating the ROI. The feature extraction function used to extract features from the cropped ROI image using one or more texture analysis methods. The extracted features are used for classification purposes. The classification function is an algorithm to predict and make a decision either the testing data is suffered from the disease or not.

The rest of this paper is structured as follows: Section 2 provides an overview of image pre-processing. Section 3 explains an overview of feature extraction. Section 4 provides an overview of classification. Section 5 serves the graph that shows all the regions that have been studied, the feature extraction used, the classification used, and the accuracy of their iris recognition system since 2017 and the conclusion of the paper in section 6 .

\section{IMAGE PRE-PROCESSING}

The image preprocessing function is used to obtain the ROI of the iris from the iris image. Generally, preprocessing is consists of five steps:

\section{A. Transform Into A Grayscale Image}

The purpose of converting the image into gray level image is to enable the process to localization the iris or separating it from the sclera and the pupil and then normalize the iris and matched it with the iridology charts [5]. Generally, this formula can convert color image to grayscale image: [6]:

$$
\begin{aligned}
& I=a \times R+b \times G+c \times B, a+b+c=1 \\
& I=0,2989 \times R+0,5870 \times G+0,1141 \times B
\end{aligned}
$$



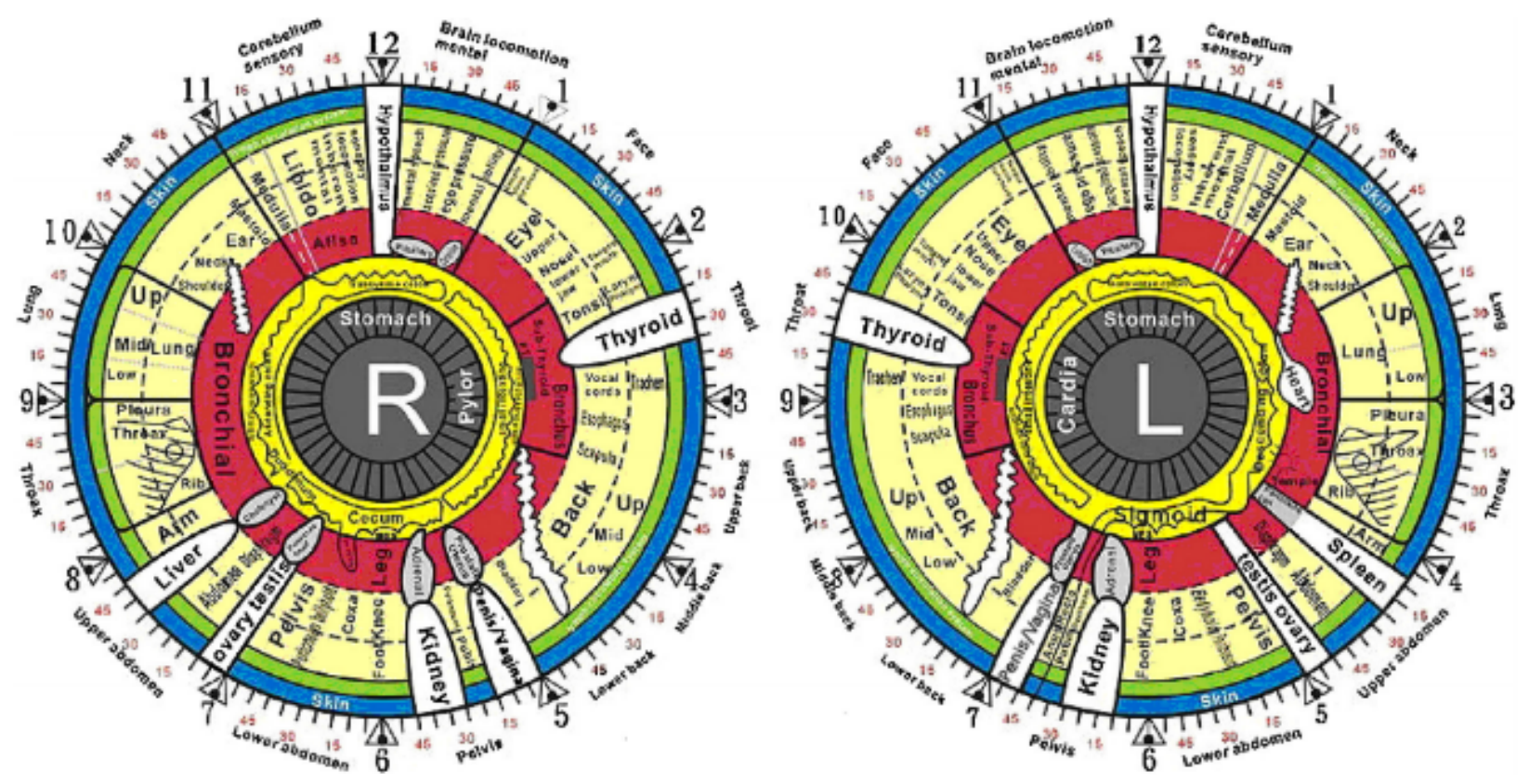

Figure 2. Iridology chart [5].

\section{B. Iris Localization}

The purpose of iris localization is to locate the outer boundaries and inner boundaries of the iris [5]. The difference of intensity between sclera, iris, and pupil can be used to locate the outer and inner boundaries. Hough Transform (CHT) is a technique that usually used for iris localization. CHT is a computer vision algorithm to determine parameters from geometric objects, such as circles and lines, in the image. The CHT technique is used to deduce the center coordinates of the pupil, the radius of the pupil, and iris regions [7].

In this transform, firstly, the first derivative of the intensity from an eye image is calculated. After that, thresholding the first derivatives result and generating the edge map. Afterward, parameters of the circle were calculated as the circle passing through each maximum edge point in the edge map. The main parameters of this algorithm are the radius and center coordinates of iris and pupil [8]. Figure 3 illustrates the process of iris localization.

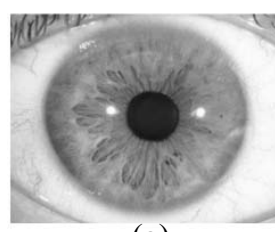

(a)

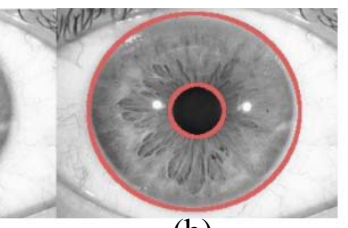

(b)

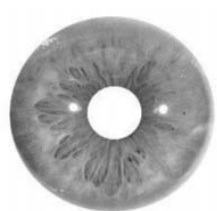

(c)
Figure 3. Iris localization stages. (a) An eye image (grayscale). (b) Two circles for pupil and iris boundaries. (c) Result of segmented iris [5].

\section{Normalization}

After localizing the iris, the image will be transformed into a rectangle form from a ring form to make it easier for analysis the image. This step is called normalization [9]. The technique that usually used to normalized the image is the rubber-sheet model. This technique remaps the iris localization image into a rectangle where one axis represents the radial angle and the other one represents the radius. Figure 4 shows the result of iris normalization. This remapping can be modeled as follows [8] and the results can be seen in figure 4 :

$I(x(r, \theta), y(r, \theta)) \rightarrow I(r, \theta)$

With

$x(r, \theta)=(1-r) x_{p}(\theta)+r x_{i}(\theta)$
$y(r, \theta)=(1-r) y_{p}(\theta)+r y_{i}(\theta)$

Where:

$I(x, y)=$ Iris region

$(x, y)=$ Original coordinates

$(r, \theta)=$ Corresponding polar coordinates

$\left(x_{p}, y_{p}\right)$ and $\left(x_{i}, y_{i}\right)=$ Inner and outer

boundaries coordinates along with $\theta$ direction
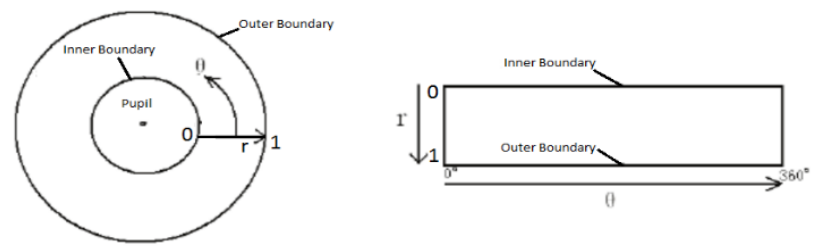

Figure 4. Iris normalization.

\section{Histogram Equalization}

Histogram Equalization is an image processing technique for improving image contrast. This technique is spreading out the intensity values that appear the most and the intensity range of an image. Histogram equalization can be performed by calculating probability and cumulative density function, calculating the number of pixels for every color, producing the total of the count, and then scaling the results. This technique is used when the usable data have close values of contrast. Therefore, this technique is suitable for iris image because the image pixels generally occupy the entire range of gray levels (0 to 255). In addition, the image has a high contrast appearance and has a large variety of gray tones [10]. Figure 5 shows the result of histogram equalization. 

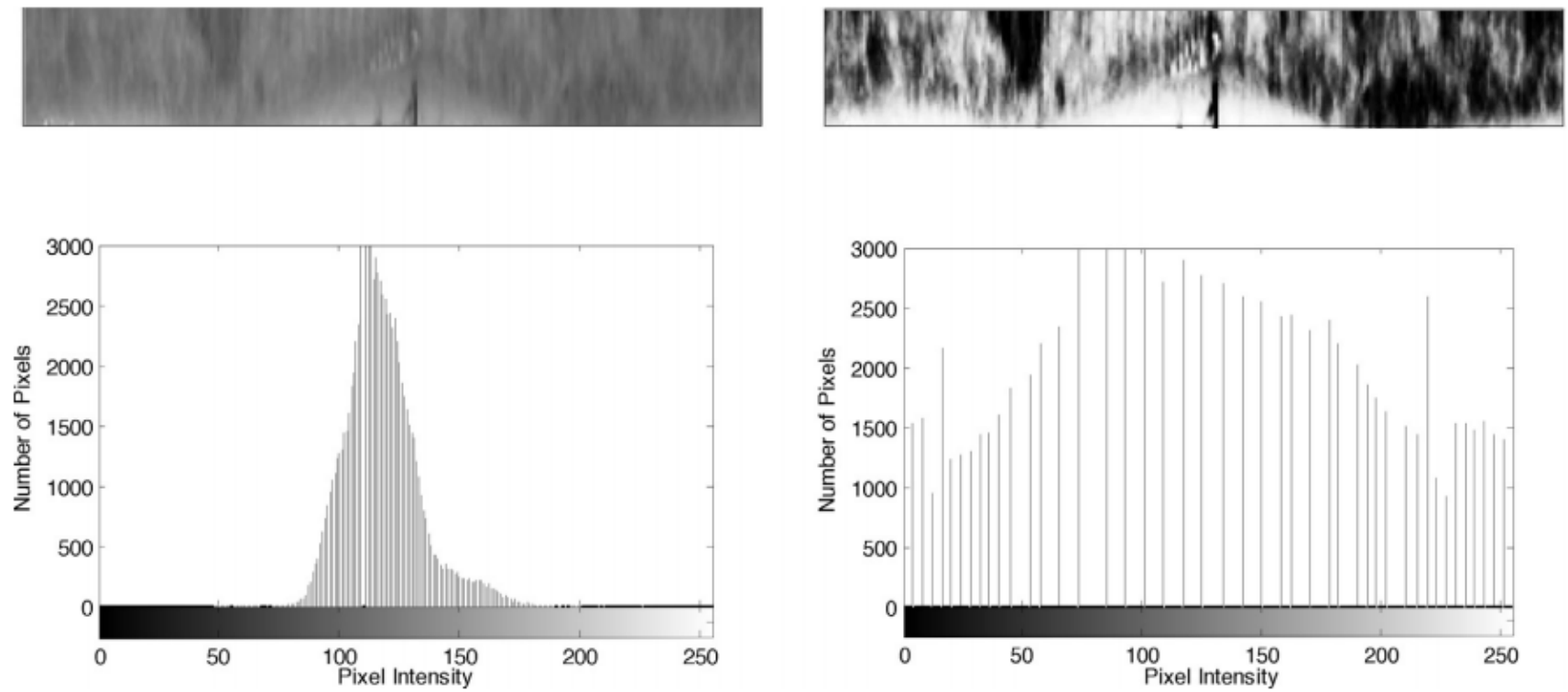

Figure 5. Histogram Equalization of an iris normalization image. Left, iris normalization image and its histogram before histogram equalization. Right, iris normalization image and its histogram after histogram equalization [5].

\section{E. Separating the ROI}

ROI is a particular part of a dataset or an image that will be identified or operate or filter for a specific purpose. In iridology, the ROI is a particular part of an iris image that represents a particular part or organ of a human body. This region will be analyzed to determine the health condition of that organ. [4].

\section{FEATURE EXTRACTION}

The feature extraction function used to extract features from the cropped ROI image using one or more texture analysis methods. The extracted features are used for classification purposes. Each researchers employed various algorithm to extract features [11]. There are some common methods to extract features:

\section{A. Black White Ratio}

Black White Ratio is a feature extraction method that calculates the white and black pixels from a binary image and divides the total number of white pixels and black pixels with the total pixels of the image. Following is the formula to calculate the ratio [12]:

$$
\begin{aligned}
& \text { White Ratio }=\frac{\text { Total of White Pixels }}{\text { Total Pixels }} \\
& \text { Black Ratio }=\frac{\text { Total of Black Pixels }}{\text { Total Pixels }}
\end{aligned}
$$

The average accuracy of this method regardless of the type of classifier is $81.91 \%$, with the highest accuracy of $92 \%$. Most studies using this extraction feature use thresholding algorithms as classifiers and also apply the auto-cropping function to their systems.

\section{B. Gray Level Co-Occurrence Matrix (GLCM)}

Gray Level Co-Occurrence Matrix (GLCM) is a feature extraction to obtain the gray level from an eye image [13]. The grayish value of an eye image is different from each other. Following is the steps to use GLCM feature extraction:
1) Initialize the matrix area.

2) Set the spatial relation of the neighbor and the reference pixel, and set the distance $d$ and the angle $\theta$.

3) Calculating the concurrency matrix with the transposes concurrency matrix to make it symmetric.

4) Transform the matrix to probability form $(P d)$ by normalizing it.

The following is the statistics characteristics of Gray Level Co-Occurrence Matrix (GLCM): 1) Energy, 2) Homogeneity, 3) Contrast, and 4) Entropy [14]. The average accuracy of this method regardless of the type of classifier is $87.31 \%$, with the highest accuracy of $97.78 \%$.

\section{2D Gabor Filter}

The 2D Gabor filter is a feature extraction that has a good ability to distinguish space dan frequency domain. The Daughman's iris recognition often uses this feature extraction [11] [15]. The average accuracy of this method regardless of the type of classifier is $88.6 \%$, with the highest accuracy of $91.8 \%$.

\section{ClassifiCATION}

The classification function is an algorithm to predict and make a decision either the testing data is suffered from the disease or not. There are some common method for classification:

\section{A. Tresholding Algorithm}

The thresholding algorithm is a classifier that classified the ratio in the image. This classifier usually used for black and white ratio feature extraction. The thresholding algorithm steps are as follow [16]:

1) Set the limit or threshold.

2) Determine the class label. The label will be used to classify the data whether it is less or over the threshold. In the research about iridology, the labels usually are named abnormal and normal. 
3) Input the data (segmented eye image) that will be classified.

4) Classify and labeling the data based on the value of the data, whether it is less or over the threshold that was set in the first step.

The average accuracy of this classifier regardless of the type of classifier is $81.91 \%$, with the highest accuracy of $92 \%$.

\section{B. Backpropagation Neural Network.}

The backpropagation neural network is an artificial neural network that has learning techniques. The backpropagation neural network is a method for solving a problem by feeding a set of data as the learning or training process [17]. This method widely used because of its ability to minimize the error of the output [14]. The average accuracy of this classifier regardless of the type of classifier is $82.5 \%$, with the highest accuracy of $83.33 \%$.

\section{Support Vector Machine (SVM)}

Support Vector Machine (SVM) is a binary classifier that uses the structural risk minimization principle. Vapnik was the proposer of this method [18]. Currently, the S method is often used for various fields such as image recognition, pattern recognition, text classification, etc [19]. Paper Cristianini [20] and Burges [21] provide more in-depth information about Support Vector Machine. The average accuracy of this classifier regardless of the type of classifier is $93.33 \%$, with the highest accuracy of $96 \%$.

\section{IRIS RECOGNITION SYSTEM ROI AND ACCURACY}

Figure 6 shows all the regions that have been studied and the accuracy of their iris recognition system since 2017. All paper that we used to make this survey are all journals and conferences which are show in the list of google scholar with the keyword of "“iridology" and "image processing." " And also we only use English and Indonesian paper. The total of the paper used to make figure 6 is 26 paper. Table 1 shows detailed data from the paper used to make the figure 6 .

The most frequently studied ROI is Arcus Senilis and Pancreas with a total of 7 papers since 2017. The highest accuracy is found in paper Ridza [23] with an accuracy value of $97.78 \%$ using Gray Level Co-Occurrence Matrix (GLCM) as the feature extraction and Bayesian regularization $(\mathrm{BR})$ classifier as the classifier.

\section{CONCLUSION}

As we can see in figure 6, most popular ROI that have been researched is Arcus Senilis and Pancreas, with the highest accuracy of $97.78 \%$ for ROI of Arcus Senilis and 95.81\% for ROI of Pancreas. The iris recognition system with the highest accuracy is in paper Ridza [23]. In this paper, they use Gray Level Co-Occurrence Matrix (GLCM) feature extraction and Bayesian regularization (BR) classification to diagnose either the subject is suffering from the disease or not.

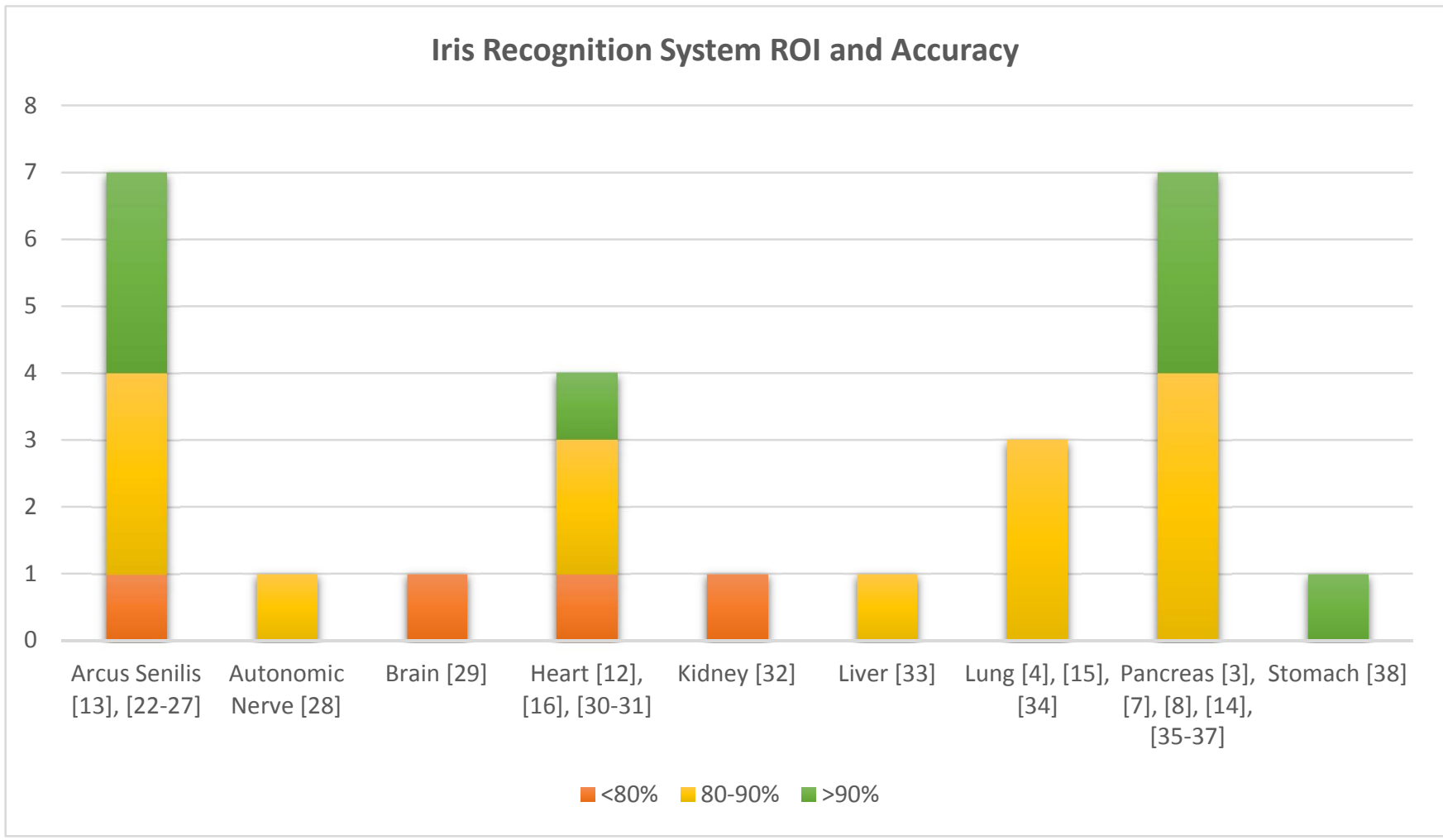

Figure 6. Graph of all paper ROI and accuracy results about iridology and image processing. 
TABLE I. DETAILED DATA OF THE 26 REVIEWED PAPERS.

\begin{tabular}{|c|c|c|c|}
\hline ROI & Feature Extraction & Classifier & Accuracy \\
\hline \multirow[t]{7}{*}{ Arcus Senilis } & Gray Level Co-Occurrence Matrix (GLCM) & Backpropagation Neural Network & $81.81 \%[13]$ \\
\hline & Gabor Filter & Otsu Threshold & $86.00 \%[22]$ \\
\hline & Grey Level Co-occurrence Matrix (GLCM) & $\begin{array}{l}\text { Bayesian Regularization (BR) } \\
\text { Classifier }\end{array}$ & $97.78 \%[23]$ \\
\hline & Fuzzy Local Binary Pattern (FLBP) & Linear Regression Analysis & $91.40 \%[24]$ \\
\hline & - & RBF & $89.00 \%[25]$ \\
\hline & - & $\mathrm{RBF}$ & $53.33 \%[26]$ \\
\hline & Histogram Of Oriented Gradients (HOG) & Artificial Neural Network (ANN) & $93.00 \%[27]$ \\
\hline Autonomic Nerve & Principal Component Analysis (PCA) & Backpropagation Neural Network & $83.33 \%[28]$ \\
\hline Brain & $\begin{array}{l}\text { Average Intensity, Average Contrast of Standard Deviation, } \\
\text { Mildness, Third Moment, Uniformity of The Histogram, Entropy }\end{array}$ & Naïve Bayes & $61.96 \%[29]$ \\
\hline \multirow[t]{4}{*}{ Heart } & Black And White Ratio & Thresholding Algorithm & $70.00 \%[12]$ \\
\hline & Black And White Ratio & Thresholding Algorithm & $83.33 \%[16]$ \\
\hline & Black And White Ratio & Thresholding Algorithm & $82.30 \%[30]$ \\
\hline & SURF-Features & $\begin{array}{l}\text { MCO-SVM (Multi-Class Oriented } \\
\text { SVM) }\end{array}$ & $96.00 \%[31]$ \\
\hline Kidney & Gray Level Co-Occurrence Matrix (GLCM) & Euclidean Distance & $70.00 \%[32]$ \\
\hline Liver & Grey Level, Enhancing and Sobel Operator & Histogram & $84.00 \%[33]$ \\
\hline \multirow[t]{3}{*}{ Lung } & $\begin{array}{l}\text { 2D Gabor filter and 2D Discrete Wavelet } \\
\text { Transform (DWT) }\end{array}$ & Support Vector Machine (SVM) & $89.00 \%[4]$ \\
\hline & 2D Gabor Filter & Support Vector Machine (SVM) & $88.00 \%[15]$ \\
\hline & Gabor Features Based Blob Detector & Support Vector Machine (SVM) & $88.00 \%[34]$ \\
\hline \multirow[t]{7}{*}{ Pancreas } & Pixel Information, Gabor Filter, HOG, and LBP & Adaboost & $91.80 \%[3]$ \\
\hline & Discrete Wavelet Transform (DWT) & Random Forest & $89.66 \%[7]$ \\
\hline & $\begin{array}{l}\text { Statistical, Texture And Discrete Wavelength Transformation } \\
\text { Features }\end{array}$ & Random Forest & $89.63 \%[8]$ \\
\hline & Gray Level Co-Occurrence Matrix (GLCM) & $\begin{array}{l}\text { Artificial Neural Network } \\
\text { Backpropagation }\end{array}$ & $82.35 \%[14]$ \\
\hline & $\begin{array}{l}\text { Statistical, GLCM And GLRL Features (With T-Test Feature } \\
\text { Selection) }\end{array}$ & EBoT (Boosted Tree) & $95.81 \%[35]$ \\
\hline & Black And White Ratio & Thresholding Algorithm & $92.00 \%[36]$ \\
\hline & $\begin{array}{l}\text { Statistical, Texture Analysis, And Two-Dimensional Discrete } \\
\text { Wavelet Transformation }\end{array}$ & Random Forest & $89.66 \%[37]$ \\
\hline Stomach & RGB Components And The Gray-Scale Transformation & Support Vector Machine (SVM) & $96.00 \%[38]$ \\
\hline
\end{tabular}

\section{REFERENCES}

[1] O. Zuraini, P. Anton Satria, "Preliminary Study on Iris Recognition System: Tissues of Body Organs in Iridology," in 2010 IEEE EMBS Conference on Biomedical Engineering \& Sciences (IECBES 2010), 2010, pp 115-119.

[2] B. Jensen on The SCIENCE and PRACTICE of IRIDOLOGY, WHITMAN Publications, 1952.

[3] P. Moradi, N. Nazer, A. K. Ahmadi, H. Mohammadzade and H. K. Jafari, "Discovering Informative Regions in Iris Images to Predict Diabetes," in 2018 25th national and 3rd International Iranian Conference on Biomedical Engineering (ICBME), IEEE, 2018.

[4] B. Atul, A. Ravinder, K. Sharma R., "Iris images based prediagnostic tool to predict obstructive lung diseases", Biomedical Research 2018; Special Issue: S517-S522.

[5] H. Sherif E., H. Osama A., G. Malcolm H., "Assessment of the potential iridology for diagnosing kidney disease using wavelet analysis and neural networks", Biomedical Signal Processing and Control 8, 2013, pp 534-541.

[6] R. Nova Ayu, Arini, S. Anif Hanifah, "Colon Detection Using Principal Component Analysis (PCA) and Support Vector Machine (SVM)," in 2016 4th International Conference on Cyber and IT Service Management, IEEE, 2016.

[7] S. Piyush, A. Ravinder, "Comparative analysis of classification based algorithms for diabetes diagnosis using iris images," Journal of Medical Engineering \& Technology, 2018 Jan, Vol. 42, No. 1, pp $35-42$.
[8] S. Piyush, A. Ravinder, "Machine learning techniques for medical diagnosis of diabetes using iris images," Computer Methods and Programs in Biomedicine, Volume 157, April 2018, pp 121-128.

[9] A. Asuntha, Y. Sree Charan, M. Siddartha, K. Udhaykumar, and S. Andy, "Identification of Diabetics Mellitus using Iridology," International Journal of Research in Pharmaceutical Sciences, vol. 10, no. 3, 2019, pp. 1821-1823.

[10] H. R. G. Alam Nusantara Putra, I. R. Rizal, Z. Ajub Ajulian, "Application of Liver Disease Detection Using Iridology with BackPropagation Neural Network," Proc. of 2015 2nd Int. Conference on Information Technology, Computer and Electrical Engineering (ICITACEE), Indonesia, Oct 16-18th, pp 123-127.

[11] L. Ma, N. Li, "Texture feature extraction and classification for iris diagnosis," International conference on medical biometrics. Lect Notes Comp Sci Springer-Verlag 2007, pp 168-175.

[12] E. M. Kusumaningtyas, A. R. Barakbah, A. A. Hermawan and S. R. Candra, "Auto cropping for application of heart abnormalities detection through Iris based on mobile devices," 2017 International Electronics Symposium on Knowledge Creation and Intelligent Computing (IES-KCIC), Surabaya, 2017, pp. 108-113.

[13] S. Agung, B. Wisnu, and R. Liani Budi, "Deteksi Kadar Kolesterol Melalui Iris Mata Menggunakan Image Processing Dengan Metode Jaringan Syaraf Tiruan Dan Gray Level Co-Occurrence Matrix (GLCM)," Prosiding Seminar Nasional Fisika (E-Journal) SNF2017, vol. 6, 2017.

[14] D. C. Adelina, R. Sigit, T. Harsono and M. Rochmad, "Identification of diabetes in pancreatic organs using iridology," 2017 International 
Electronics Symposium on Knowledge Creation and Intelligent Computing (IES-KCIC), Surabaya, 2017, pp. 114-119.

[15] B. Atul, A. Ravinder, K. Sharma R., "Pre-Diagnostic Tool to Predict Obstructive Lung Diseases Using Iris Recognition System," In: Smart Innovations in Communication and Computational Sciences. Advances in Intelligent Systems and Computing, vol. 669, pp. 7179, 2019.

[16] F. D. Kusuma, E. M. Kusumaningtyas, A. R. Barakbah, and A. A. Hermawan, "Heart Abnormalities Detection Through Iris Based on Mobile," 2018 International Electronics Symposium on Knowledge Creation and Intelligent Computing (IES-KCIC), Bali, Indonesia, 2018, pp. 152-157.

[17] A. Hermawan, "Jaringan Saraf Tiruan Teori dan Aplikasi." ANDI, Yogyakarta, p. 208, 2006.

[18] C. Cortes, V. Vapnik on Support vector networks-Machine Learning, Kluwer Academic Publishers, Boston. 1995; pp. 273-297.

[19] K. Kyung-Ah, C. Joon Yul, Y. Tae, K. Sung, C. Kilsoo, and K. Deok Won, "Mortality prediction of rats in acute hemorrhagic shock using machine-learning techniques," Medical Biological Engineering and Computing,vol. 51, no: 9, 2013, pp. 1059-1067.

[20] N. Cristianini, D. Shawe T, "An introduction to support vector machines and other kernel-based learning methods," Cambridge University press, Cambridge.

[21] C. Burges CJ on A Tutorial on Support Vector Machines for Pattern Recognition, Kluwer Academic Publishers, Boston, 1998.

[22] S. Louis, N. Indri, L. Rina, Z. Situlus, and Z. Mariana., "The Expert System of Cholesterol Detection Based on Iris Using the Gabor Filter." SinkrOn, vol. 4, no. 1, 2019, pp. 13-18.

[23] R. Ridza Azri, R. Abd Rahman, H. Marsyita, N. Zarina Mohd, and K. Asem, "Classification of Eye Abnormality Using Statistical Parameters in Texture Features of Corneal Arcus Image," Advanced Science Letters, vol. 24, no. 6, 2018, pp. 4063-4069.

[24] S. N. Andana, L. Novamizanti and I. N. Apraz Ramatryana, "Measurement of Cholesterol Conditions of Eye Image using Fuzzy Local Binary Pattern (FLBP) and Linear Regression," 2019.

[25] A. Anjarsari, D. Auli, P. Asri, and E. Winarko, "Hybrid radial basis function with firefly algorithm and simulated annealing for detection of high cholesterol through iris images," in 9th Annual Basic Science International Conference 2019 (BaSIC 2019), IOP Conf. Series: Materials Science and Engineering, vol. 546, 2019.

[26] Y. Daniel Hadrian, W. I Made Nomo, F. Tea Qaula, "Identifikasi Pola Penyakit pada Citra Iris Mata dengan RBF Neural Network," Jurnal Informatika, vol. 5, no .2, 2018, pp. 195-201.

[27] S. Muhammad Arsyad, N. Ledya, R. I Nyoman Apraz, "Deteksi Level Kolesterol melalui Citra Mata Berbasis HOG dan ANN," ELKOMIKA, vol. 7, no. 2, 2019, pp. $284-296$.

[28] E. Wicaksono, I. Santoso, A. Zahra, and R. Isnanto, "Identifikasi Kerusakan Saraf Autonomik Melalui Citra Iris Mata Menggunakan Ekstraksi Ciri Analisis Komponen Utama (Pca) Dan Jaringan Saraf Tiruan Perambatan Balik," Jurnal Ilmiah Teknik Elektro, vol. 6, no. 3, 2017, pp. 254-258.

[29] F. Hernandez, R. Vega, F. Tapia, D. Morocho and W. Fuertes, "Early detection of Alzheimer's using digital image processing through iridology, an alternative method," 2018 13th Iberian Conference on Information Systems and Technologies (CISTI), Caceres, 2018, pp. $1-7$.

[30] M. Entin, B. Ali, and H. Aditya, "Feature Extraction For Application of Heart Abnormalities Detection Through Iris Based on Mobile Devices." EMITTER International Journal of Engineering Technology, vol. 5, no. 2, 2018, pp. 312-327.

[31] N. Benedictor and L. Li., "Iris features-based heart disease diagnosis by computer vision," in Ninth International Conference on Digital Image Processing (ICDIP 2017), Proc. of SPIE Vol. 10420, 2017.

[32] A. Siska and Herman, "Peningkatan Kualitas Citra Iris Mata Menggunakan Operasi Piksel Dan Ekualisasi Histogram Untuk Pengklasifikasian Kondisi Kesehatan Ginjal," Seminar Nasional Teknologi Informasi dan Komunikasi STI\&K (SeNTIK), vol. 2, 2018.

[33] S. Maxima Ari, "Mendeteksi Kondisi Organ Liver Melalui Citra Iris Menggunakan Teknik Pengolahan Citra Digital (Detecting the Condition of Liver Organ Through Iris Image Using Digital Image Processing Techniques)." JEEE-U (Journal of Electrical and Electronic Engineering-UMSIDA), vol. 3, no. 1, pp. 138-161, 2019.
[34] H. Tassadaq, M. Abdul, A. Muhammad, A. Taleb, and A. Eduard, "An Iris based Lungs Pre-diagnostic System," 2019 2nd International Conference on Computing, Mathematics and Engineering Technologies (iCoMET), Sukkur, Pakistan, 2019, pp. $1-5$.

[35] P. Samant \& Agarwal, "Analysis of computational techniques for diabetes diagnosis using the combination of iris-based features and physiological parameters," Neural Computing and Applications, vol. 31, issue 12, pp 8441-8453, 2019.

[36] E. M. Kusumaningtyas, A. Barakbah and A. Salsabil, "Auto Cropping for Application of Pancreas Abnormality Detection in Order to Recognize Diabetes Mellitus Through Iris Based on Mobile Devices," 2018 International Electronics Symposium on Knowledge Creation and Intelligent Computing (IES-KCIC), Bali, Indonesia, 2018, pp. 287-291.

[37] S. Piyush, A. Ravinder, "Diagnosis of Diabetes Using Computer Methods: Soft Computing Methods for Diabetes Detection Using Iris," World Academy of Science, Engineering and Technology International Journal of Biomedical and Biological Engineering, vol. 11, no. 2, 2017

[38] V. Carrera E., J. Maya, "Computer Aided Diagnosis of Gastrointestinal Diseases Based on Iridology." In: Botto-Tobar M., Pizarro G., Zúñiga-Prieto M., D’Armas M., Zúñiga Sánchez M. (eds) Technology Trends. CITT 2018. Communications in Computer and Information Science, vol. 895, pp. 531-541, 2019. 